\title{
ECONOMIC EQUALITY AND SOCIAL WELFARE: POLICY PREFERENCES IN FIVE NATIONS
}

Nate Breznau, breznau.nate@gmail.com

\begin{abstract}
Welfare policies are a common feature of many societies and often strongly favored by the public. This is a primary reason that every advanced capitalist nation remains a welfare state (Brooks \& Manza, 2007). Research abounds on welfare policy differences across nations yet scholars pay less attention to why and how the public formulate opinions on welfare policies. The following analysis shows evidence that the public are not merely self-interested in their policy preferences. I propose instead that they have a further goal in mind unrelated to material gains: the reduction of social inequality. I investigate this possibility using survey data from large, representative national samples in Australia, Bulgaria, the Netherlands, Finland, and Poland $(N=13,294)$. Structural equation estimates correcting for measurement error show that those with economic egalitarian values are much more supportive of welfare policies consistent with instrumental rationality theory. These egalitarian values are more important than self-interest and national institutions in shaping preferences for government control of social services, price controls for basic needs, and subsidies for basic needs. This holds true after controlling for policy regime, attitudes toward government, family income, education, occupational status, sex, age, and church attendance and holds in all five nations.
\end{abstract}


Social welfare policies are a common feature of many societies. Policies related to employment and unemployment are some of the most common features of welfare states, but legislation and provisions abound in other areas related to health care, education, care for the young and elderly, basic foods, and housing. Research suggests that public opinion favors many forms of social welfare policies (Brooks \& Manza, 2007; Papadakis \& Bean, 1993; Rockoff, 2004; Taylor-Gooby, 2001). Yet, less is known about how and why the public formulate their opinions toward such policies, especially due to the fact that the research is predominantly based on U.S. samples.

The formation of public opinion is the subject of much debate. Centuries ago in the classic Leviathan, Hobbes (1994) made a strong case for human actors as motivated purely by self-interest. This notion echoed throughout the ages in the work of many economists, including the extensive work of Marx (1887/1927) on expounding a materialist theory. Others, such as Weber $(1947 ; 1921 / 1968)$ were convinced that material foundations were not the prime mover of opinions. Weber suggested that humans tended to align opinions (and behaviors) with their ideal goals for society, a theory known as instrumental rationality. Finally, a third addition to this debate is the notion that opinions are a product of institutional context. Institutional theory posits that opinions are altered over time to align with the culture and ideology of a given policy regime or organizational context (Scott, 2001).

Following the predictions of these attitude formation theories, public preferences for social welfare policy should follow divergent paths. If the public are purely self-interested, those who have greater access to resources and more education should be less supportive of welfare policies. This is because they stand to lose the most from redistribution of their wealth or interference in their earning potentials. If public opinions are a product of institutional context, then preferences for welfare policies should follow the norms and values instilled by policy regimes. For example, citizens of formerly Communist nations should have opinions in favor of more welfare assistance by the government, consistent with this institutional doctrine of late. Finally, if the public are instead ideologically motivated and, for example, they are more egalitarian; then they should support social welfare policies. 


\section{SUPPORT OF SOCIAL WELFARE}

Welfare policies address the needs of vulnerable members of the population. Policies related to employment and unemployment are central to welfare research (Esping-Andersen, Gallie, \& Hemerijk, 2002). There are, on the other hand, many other issues that place members of the public in vulnerable positions unrelated to income maintenance, pensions and the like. These include health care, education, nutrition, housing, and care for the young and elderly. Such policies involve a nexus of welfare expenditures, bureaucracy, and legislation. It is true that throughout history religious organizations and private philanthropy were and remain today major augmenters to government provisions of welfare, but this analysis looks only at the role of national governments. I look at three policies that extend beyond employment: government delivery of social services, price controls for basic needs and subsidies for basic needs.

Economists and especially policy makers tend to oppose governmental control of social services. Classical economic theory favors private over public delivery of social services arguing that the market is the most efficient instrument for distributing resources and services (Hacker, 2004; Parry, 1997). Policy and budget makers too are leery of such services as they require government spending (Barnekov \& Raffel, 1990). Social services are often the first to see cuts in times of economic crisis. The recent global economic crisis stands to bring a wave of service cuts in education, elderly and day-care services, and health care (Walker, 2009).

Economists also oppose price controls and subsidies for welfare related goods and services. Economists traditionally oppose price controls because they distort market forces leading to underproduction (Block, 1995), dissembled industrial bookkeeping (Mills, 1975), and concentration of industry and over powering trade unions (Lipsey, 1977). Subsidies do not fare well either with economists because they lead to over production, over supply and "deadweight losses" (Gorter, Nielson, \& Rausser, 1992, p. 28), inhibit natural efficiency (Hayek, 1943/1996), and lead to unnecessary environmental degradation and taxation (Beers \& Bergh, 2001; Myers \& Kent, 2001). There are some economists who 
see market intervention measures as useful in times of market crisis (Rockoff, 1981), or to facilitate the transition from centrally planned to free market economies (Alexeev \& Leitzel, 2001), but these are specific historical moments and the classical economic standpoint is to let the market find its own equilibrium.

The general attitudes of the public toward social welfare policies are mixed, with majority support tending to favor various state provisions of social welfare in advanced democratic nations (Bean \& Papadakis, 1998; Brooks \& Manza, 2007); thus, public opinion is not a singular entity and I use "(the) public" in this paper in the plural sense as it logically represents a host of attitudes and opinions. For example, western nations showed somewhat even splits between public supporting and opposing welfare policies in the 1980s with social democratic nations showing more unanimous support (T. W. Smith, 1987; Bean \& Papadakis, 1998) and in the mid 1990s liberal and post-Communist publics tended toward a mean support above the midpoint on a Lickert-scale (see Table 1). Many find a majority of the public supporting domain specific welfare realms; for example, Papadakis \& Bean (1993) find majority support for government provision of health care and decent living standards for the elderly in a handful of Western nations, and Lipsmeyer (2003) in a study of seven post-Communist countries finds that a majority are supportive of the government providing health care and decent housing, and reducing income inequality. In the U.S., government headed child care programs are popular (Henderson, Monroe, Garand, \& Burts, 1995), in the EU the public throughout the 1980s and 1990s were committed to core employment and living standard welfare provisions (Taylor-Gooby, 2001), and welfare programs worldwide are popular despite strong public commitment to free-market capitalism (Brooks \& Manza, 2007). The public find welfare policies popular if they explicitly target the welfare of more vulnerable members of the public (Rockoff, 2004) and only in specific cases where the public tend to perceive services for the more vulnerable as failing are they willing to support privatization (Thompson \& Elling, 2000). This paper investigates 3 sources of such sustained public support throughout the world. 


\section{DERIVED HYPOTHESES}

\section{MATERIAL SELF-INTEREST AND SOCIOECONOMIC STATUS}

A long standing theory on the nature of human opinions and behaviors is that they derive from self-interest. This postulate dates back to the work of Hobbes (1651/1994) and is central to the work of many economic theorists such as Smith (2003), Ricardo (1817/2006), Marx (1887/1927), and Friedman (1962/2002). These theorists assert that the basic drives of humans in society are a product of access to materials (Marx, 1887/1927; Miller, 1999; Papadakis, 1993). Materials include basic necessities such as food and shelter, and on a social level translate into ownership and control of capital. Marx and other selfinterest theorists suggest that social actors seek to maximize material standing. Self-interest in the strictest sense suggests that individuals will only support policies that offer them personal economic maintenance or gain. Materialism and its descendants are diverse and therefore I focus here only on the self-interest aspect of materialist theory and label this simply "self-interest theory".

Self-interest theory has a host of support with respect to welfare policy. Those with more to gain are more supportive of given policies based on measures of socioeconomic status (SES) (R. A. Cnaan, Hasenfeld, A. Cnaan, \& Rafferty, 1993; Hasenfeld \& Rafferty, 1989; Jæger, 2006). For example, actors aim to advantage themselves vis-à-vis the income of others (Meltzer \& Richard, 1981) or their own unemployment experience (Gelissen, 2000); others demand public insurance given a volatile private market for health care (Barr, 2000); and specialized workers tend to support job protection policies (Iversen \& Soskice, 2001).

Based on self-interest theory, socioeconomic status should have a heavy impact on welfare policy preferences. SES represents the structural location of given actors and should lead to rational and selfinterested choices to maximize this location, including policy preferences. Those higher in SES will have more to lose by promoting social welfare policies that spend their tax dollars, redistribute their wealth, or impose economic constraints that will impede their maintenance and acquisition of wealth through the 
marketplace. Conversely, those lower in SES should support social welfare if they struggle to afford basic needs.

\section{H1: Those with more to gain from a welfare policy will be more supportive.}

\section{INSTITUTIONALISM AND COMMUNIST VERSUS CAPITALIST REGIMES}

Institutional theory, synonymous here with organizational theory, predicts that institutions are forces that shape policy preferences. Institutions are conglomerations of human agents interacting to achieve a communal goal or set of goals. National governments are institutions that impact and reproduce the values of their citizens in a cultural and political manner aiming to maintain, strengthen, and reproduce values and norms expressed in the existing institutional arrangements and policies (DiMaggio \& Powell, 1983; Rothstein, 1998; Scott, 2001, 1987, 2008).

Institutional theory posits that institutional norms develop and strengthen over time so long as the institution continues to exist and maintain a degree of authority in the social interactions of its members. As Scott (2001) points out, based in part on the work of Weber on bureaucracy and the organizational theory of Selznik:

As organizations become infused with value, they are no longer regarded as expendable tools; they develop a concern for self-maintenance. By taking on a distinctive set of values, the organization acquires a character structure, an identity. Maintaining the organization is no longer simply an instrumental matter of survival but becomes a struggle to preserve a set of unique values (p. 18-19).

The leaders of organizations thus strive to uphold institutional values to the best of their abilities or face replacement if they fail to do so. An institution will have an influence on policies and other formal codes that is sufficiently large to ensure the maintenance of individual norms, goals, and opinions; else it breaks down (Scott, 2001).

The influence of national institutions is well-supported empirically. In a comparative study of 24 nations by Blekesaune and Quadagno (2003) policy preferences are found to be closely linked to national institutions. In the specific realm of welfare, Esping-Andersen (1990), Svallfors (1997), and Larsen (2008) all find variations of redistributive policy preferences based on national institutional context. 
Further scholarship points out the embeddedness of institutional culture over time and finds that it can maintain an impact on public opinion (policy preferences) even after dissolution of the institution (policy regime change) (Jepperson, 1991).

Recent studies questioning institutional processes suggest that institutionalists have the institution-individual relationship backwards. These works find that individuals instead shape institutional structure, not just at inception but in a continual manner (Brooks \& Manza, 2007, 2006; Burstein, 2003; Burstein \& Linton, 2002; Hill \& Hinton-Andersson, 1995; Jacobs, 1992; Mehrtens III, 2004), although much work remains to be done on the function and extent of this (Burstein, 2006; Campbell, 2002).

Regardless of the direct effects of institutions on policy preferences and the reverse, both sides posit that the individual reflects the institution or vice-versa. The public, whether shaping or being shaped by institutions represent opinions reflective of the institution. Therefore, in traditionally capitalist nations, the public should be less supportive of social welfare policies compared with those in formerly Communist nations. In the societies that experienced a transition from total regulation of production, prices, and distribution of goods and services to market regulations; the public's internalization of the norms and goals of the former should lag behind the actual economic changes taking place. As some point out, citizens of post-Communist nations maintained strong commitments to social welfare despite views open to market freedom in the 1990s (Arts \& Gijsberts, 1998; Roller, 1994).

\section{H2: Citizens of formerly Communist nations will be more supportive of welfare policies than those who are not.}

\section{ECONOMIC EGALITARIANISM AND INSTRUMENTAL RATIONALITY}

Instrumental rationality suggests that an actor who desires a goal will rationally support things consistent with the achievement of that goal; for example social policies. If not, the actor will instead give up that goal. This process of instrumental rationality derives from Weber's writing on ends justifying the means, or zweckrational (Bratman, 1999; Eastwood, 2005; Kalberg, 1980; Weber, 1947, 1921/1968). Goals constitute subjective ideals such as the belief that one should become rich or that there is an afterlife. Means-ends rationality suggests that people holding such ideal goals would not merely wish for 
them but would make rational decisions to get a high paying job and make sound investments, or to follow the 'righteous' path and whatever stipulations apply to get to the afterlife.

Support of economic equality, an egalitarian value, is an example of a goal that individuals might foster, one that subsequently should align their policy preferences toward greater welfare provisions. Egalitarian ideology consists of beliefs that there is too much difference between rich and poor, and that society should do something about it. These beliefs should produce rational actions or policy preferences with the potential to contradict material inequalities. It follows that those with weaker or anti-egalitarian values should be less supportive or in opposition to welfare policies.

H3: Those with greater economic egalitarian values will be more supportive of welfare policies.

\section{IDEOLOGY AS INTERVENER}

Ideologies develop out of a variety of structural and institutional forces. Scholars note that selfinterest drives ideologies and those further up the SES ladder have more commitment to individualism as opposed to egalitarianism (discussion in Hasenfeld \& Rafferty, 1989). Others show that socialization determines ideologies and those raised under liberal markets with democratic principles will have strong commitments to economic individualism with simultaneous commitments to basic levels of egalitarianism; whereas those socialized under Communism will favor ideal levels of egalitarianism as subordination to Communist doctrine (Arts \& Gijsberts, 1998). Thus, both political institutions and selfinterest shape egalitarian values and might blur the apparent relationship of ideology with policy preferences. I test this issue by using a two stage model that measures first the influence of egalitarianism on policy preferences independently (H3), and second measures this influence while controlling for selfinterest and institutional factors (H1 and $\mathrm{H} 2$ ). In other words, I operationalize egalitarian values as an intervening variable between SES and institutions and the dependent policy preference variables. If selfinterest or institutional regime have important effects on egalitarian values, then the second model will show a large increase in the explained variance (r-squared) and a large decrease in the effects of egalitarian values on policy preferences (standardized coefficients); conversely, if the proposed influence 
of self-interest and institutions on egalitarian values is small then the variance will not change much and the effects of egalitarianism will remain robust.

\section{DATA AND MEASUREMENT}

\section{CASE SELECTION}

Existing research finds that egalitarian ideology is a primary force predicting levels of support for various welfare policies; yet, this research is mostly based on Western, highly developed nations (Gelissen, 2000; Jæger, 2006), mostly the United States. Some of the critical findings also derive from small, urban samples (Feldman \& Steenbergen, 2001; Hasenfeld \& Rafferty, 1989). To further investigate these findings both representatively and cross-nationally, I select large scale national samples from outside the U.S. in Australia, Bulgaria, Finland, the Netherlands, and Poland. American exceptionalism and the relationship of racism to welfare attitudes make findings from the U.S. suspect to cross-national comparison (Lipset, 1997; Alesina \& Glaeser, 2004). I instead select Australia as a highly developed Western alternative to extend the work done on the U.S. samples. Comparing this liberal capitalistic economy with social democratic regimes in the Netherlands and Finland provides insights into policy preference formation in publics that live in dramatically different settings; arguably more opposite in welfare state typologies (Esping-Andersen, 1990). Testing these hypotheses in formerly Communist nations of Poland and Bulgaria offers further comparisons to citizens of emergent or future welfare states who have radically different, fully socialized, histories of social policy under Communist rule. Finally, looking at two instances of post-Communism in Poland and Bulgaria offers investigation of divergent developmental paths. Poland was rather successful in early transition compared with Bulgaria's turbulence and economic difficulties (Blanchard, 1997).

The formerly Communist nations provide a unique 'natural' experiment for investigating institutional effects on individuals. Unlike more democratically formed governments, soviet tanks forced the Communist institutional regime upon the Eastern European nations. If the predictions of institutional theory are wrong, there should be less difference in policy preferences in formerly Communist nations 
when compared to others. Even though Poles and Bulgarians prior to 1989 espoused some socialist tendencies, Communism represents a unique socializing 'experiment' versus a more organic evolution of governing style.

\section{DATA}

The International Survey of Economic Attitudes (ISEA) is a survey started in 1991 and conducted in subsequent waves (Kelley, Evans, \& Zagorski, 2007). The ISEA data used in this analysis are pooled cross sections from 1994 to 1999 in Australia, Bulgaria, the Netherlands, Finland, and Poland (Kelley, Evans, \& Zagorski, 1999/2007) as the surveys were started and completed at different points during this period. The respondents include a representative sampling of each country $(N=13,294)$. A comparison with national census data confirms that the ISEA data are sufficiently representative national samples from the mid 1990s (Sikora, 1997). The Australian data were based on simple random samples of Australians conducted by the ISEA principals. The data are from 1994, 1995, and $1999(N=5,572)$ with a response rate (RR3) of 62 percent. The Institute of Sociology, Bulgarian Academy of Sciences completed the Bulgarian edition in 1997 ( $N=1,273$; RR3=85 percent). Turku University conducted the Finnish edition in 1994 ( $N=1,720$; RR3=56 percent). The Center for Social Opinion Research did the Polish edition in 1994 and 1997 (N=3,796; RR3=90 percent). Interuniversity Center for Social Science Theory and Methodology completed The Netherlands edition of the survey in 1998 ( $N=933$; response rates unavailable). For further details on survey methods in Australia, Bulgaria, Finland and Poland see Sikora (2005, p. 241).

\section{MEASUREMENT}

Measurements of independent variables with means, standard deviations, and test re-test reliabilities; and multi-item scale means, standard deviations, and alpha reliabilities are presented in Table 1. Self-interest variables include family income, education, and occupational status. Family income is the ratio of the respondent's family income to the average wages of semi-skilled, full-time male workers in 
the respondent's country. I measure education in years of school completed. Occupational status is a scale from 0 to 100 consistent with Worldwide Status Scoring (Kelley, 1990); for example 0 would be an unskilled farm laborer and 100 a high level professional. Male is dichotomous for sex with males scored as 1 and females as 0 . Church attendance is the natural log of days attended per year, with "never" recoded as 0.5. Age is in years. National institutions are formerly Communist regimes coded 1 and others coded 0.

Question wording and means for multi-item intervening variables egalitarian values and government effectiveness, and latent variables government control of social services, price controls, and subsidies are in Tables 2-6 respectively showing the face validity of the scales. The measurement of egalitarian values includes five questions that ask about differences in income and wealth in society; government effectiveness includes three questions about the quality of government services; government control of social services includes six questions about the role of the government in service provisions; subsidies includes four questions asking about subsidization of various basic goods; price controls includes four questions specifically asking about governmental regulation of prices.

Tables 2-6 also show the interval scoring for each response category on a scale from 0 to 100 . Although recoding questions with a four- or five-point set of answer categories to equal intervals is conventional, and alternative coding generally yields the same results as equal intervals scoring (Cramer, D. L. Howitt, \& D. Howitt, 2004), in this analysis ordinal probit regressions predicting intervals for each scale item for dependent and intervening variables reveals some substantial deviation from equal intervals. In other words coding the variables with 0 to represent strongly disagree, 25 somewhat disagree, 50 neutral, 75 somewhat agree, and 100 strongly disagree does not capture the differences in respondents' attitudes between response categories. This divergence warrants the use of predicted intervals as opposed to equal intervals (for details see Technical Appendix at http://www.international-survey.org). As discussed earlier the public tend to support social welfare policies and looking at Table 1 the respective means for government control of social services, price controls, and subsidies are 57.6 (neutral coded at 39), 49.8 (no logical midpoint, some price controlling coded at 10 and total controlling coded at 100) and 
54.1 (neutral coded at 30). These numbers show that the public tend to be on the favoring side for each social welfare policy; i.e. the average response being greater than "neutral" or "some" based on relative scoring intervals. Also for each scale item high alpha reliabilities suggest strong construct validity. Not shown are the appropriately large inter-item correlations, similar correlations with other variables and factor analyses confirming one underlying factor per concept, in total and holding within each country, further demonstrating appropriate construction of each scale (see Technical Appendix).

(Table 1 about here)

Table 2 shows measurement of egalitarian values, the notions that a person's society is unequal and that it is ideal to reduce this inequality. The specific measurement of egalitarian values is based on answers to five questions: "Do you agree or disagree..." that: "Differences in income in [respondent's country] are too large"; "It is the responsibility of the government to reduce the differences in income between people with high incomes and those with low incomes"; "There is too much of a difference between rich and poor in this country"; "Income and wealth should be redistributed toward ordinary people"; and "One of the most important aims in this country over the next ten years should be to reduce the differences between rich and poor." Based on predicted probit modeling, if the respondent strongly disagrees with the statement I code it a 0 , somewhat disagree 7 , neutral 29 , somewhat agree 53 , and strongly agree scored 100 . As the first row of numbers in the table demonstrates, 1 percent of respondents strongly disagreed that differences in income in their country were too large, while 10 percent somewhat disagreed, 13 percent neutral, 37 percent somewhat agreed, and 39 percent strongly agreed. The average response for the question was 63 , or just above somewhat agree. Similarly the average response to the government's responsibility to reduce differences in income was 51, too much difference between rich and poor 65 , income and wealth should be redistributed 52, and the most important aim over the next 10 years is to reduce differences 56. Overall, these numbers show that the public on average are somewhat or strongly in favor of reducing economic inequality.

(Table 2 about here) 
The measurement of government effectiveness in Table 3 comes from responses to the question "Government and private enterprises both have their good points and bad ones. Which do you think is..." and includes the items "Most efficient, most productive?", "Most flexible, responds quickly to new opportunities and new conditions?”, and “Most profitable?" I recoded responses into predicted unequal intervals so that if the respondent says that private enterprise is extremely more effective than the government it is coded 0 , somewhat more 24 , both are equally effective 50 , government is somewhat more effective 85 , and government extremely more effective 100 . In the first row for example, when asked about which is "Most efficient, most productive?", 23 percent of respondents said private is most effective, 49 percent felt it somewhat more effective, 15 percent thought private and government enterprise were equally effective, 10 percent said that government was somewhat more effective, and 4 percent government most effective. The average score is a 31 suggesting that most members of the public see government as somewhat less effective than private enterprise. Similarly the average for flexibility was 26 , and for profitability 32 , demonstrating an overall tendency to favor private enterprise amongst those surveyed.

(Table 3 about here)

The measurement of government control of social services in Table 4 comes from responses to the question: "What part should the government play in running companies in these industries..." and includes items "hospitals", “doctors and dentists", "schools", "universities", "day-care centers for children", and "old age homes". I recoded responses into predicted intervals so that if the respondent says that the government should have no role it is coded 0 , some role 10, regulate important aspects but leave the day-to-day alone 12, and regulate all aspects 100. In the first row for example, when asked about hospitals, 2 percent of respondents say no role, 21 percent some, 39 percent important aspects, and 39 percent all aspects. The average score is a 67 , in other words, the public tend to believe that the government should run some or all aspects of social services. Similarly the average for doctors and dentists is 52, schools 63 , universities 57, day-care 50, and old age homes 57. Overall, the public support some degree, if not full, government provision of social services. 
(Table 4 about here)

The measurement of price controls in Table 5 comes from answers to this four item question battery: "Should the government regulate prices or should they be set by the free market?" for "electricity", "basic foods", "rent for houses and flats", and "doctor's fee and hospital charges". I recode questions with unequal intervals for each of the five 'points' of potential responses. I recoded the answers so that if the respondent says they should be set entirely by the free market it is a score of 0 , if they say mostly set by the free market it is 16 , if they are neutral 39 , mostly by the government 52 , and if they should be set entirely by the government 100. In the first row for example, when asked about price controls for electricity, 5 percent of respondents say that it should be set entirely by the free market, 16 percent mostly by the free market, 19 percent neutral, 35 percent mostly by the government, and 26 percent entirely by the government. The average score is a 54, in other words, there is more overall support of the government regulating the price of electricity than not. The means of the other items show a similar pattern with average support for basic foods at 43 , rents for houses and flats 43 , and doctor's fee and hospital charges 59. Overall the public tend to favor price controls for basic needs.

(Table 5 about here)

The measurement of subsidies in Table 6 comes from the results of this question: "To keep prices low, should the government subsidize the production of..." and it asks for "electricity", "basic foods", “construction of houses and flats", and "doctors and hospitals". Here again I recoded responses based on probit scores so that if the respondent says government should definitely not subsidize it is a 0 , probably should not 11, neutral 30, government probably should 57, and if the government definitely should 100. In the first row for example, when asked about subsidies for electricity, 6 percent of respondents say that the government should not subsidize, 17 percent probably should not, 16 percent neutral, 35 percent probably should, and 26 percent definitely should. The average score is a 51, in other words, there is more support of the government subsidizing electricity than not. Similarly the average for basic foods is 46 , construction of houses and flats 48 , and doctors and hospitals 70 . Overall the public tend to favor government subsidies for basic needs. 
(Table 6 about here)

\begin{abstract}
ANALYSIS
STRUCTURAL MODEL

Structural equation modeling (SEM) correcting for measurement error reveals that those who espouse egalitarian values are more supportive of the three types of social welfare policy shown in Diagram 1. Structural modeling is now a mainstream statistical tool for social scientists and affords greater accuracy and prowess over OLS regression and as a review by Wolfle (2003) reaffirms it should be utilized whenever possible as it best accounts for unobserved variables, and deals with measurement error and test retest reliabilities (Jöreskog \& Sörbom, 1982).

I present standardized coefficients in the following model to demonstrate the relative impact of the causal variables on the dependent variables (for those not used to SEM these offer the same information as OLS coefficients). Diagram 1 presents the evidence that egalitarian values exert large influences on support for government control of social services, price controls, and subsidies. This influence is of magnitude $0.26,0.33,0.40$ respectively out of a possible 1.00 . This large influence is present after accounting for demographics, SES, national institutions, and opinions toward the effectiveness of government provisions.
\end{abstract}

The diagram also presents evidence that being from a formerly Communist nation influences support for all three welfare policies albeit slightly less so than egalitarian values; 0.27 for government control of social services, 0.20 for price controls and 0.20 for subsidies. Socioeconomic factors play a smaller part. SES measures have an overall combined influence on government control of social services, price controls and subsidies equal to or less than a third the influence of egalitarian values at $-0.10,-0.14$, and -0.15 respectively. The negative sign shows that those higher in SES have lower levels of welfare policy support. There is a relationship between education, income, and status of occupation, but these do not measure one underlying concept. This model should be understood only as a representation of the combined effect of all three, also known as a sheaf coefficient, while keeping in mind that they do not 
measure one common underlying factor. The sheaf represents self-interest overall for ease of comparison with institutionalism and instrumental rationality. To help deal with this issue, I create a baseline structural model to test the influence of each SES measure individually (see Table 8). As shown in these tables the individual influences of the SES variables are much smaller than institutional and especially ideological influences. The model in the diagram includes the demographic variables age, sex, and church attendance, but they are not shown as they have little to no influence on policy preferences, the results for these variables and all independent variables presented in Tables 7 and 8 .

(Diagram 1 about here)

Also shown in Diagram 1 are the relatively large effects that institutions and SES exert on egalitarian values ( 0.29 and -0.28 out of 1.00$)$. Therefore I decompose the model in two stages to test the extent, if at all, that these two variables explain the relationship between egalitarian values and public preferences. The first stage shown in Table 7 shows the large influence of egalitarian values controlling only for attitudes toward government effectiveness and demographics. The second stage shown in Table 8 demonstrates the added influence of SES and formerly communist institutions. The large influence of SES and demographics on egalitarian values $(0.29$ and -0.28$)$ does little to change the explanatory power of egalitarian values influencing policy preferences, evidenced by a fractional or nominal $r$-squared change between the first and second stages; from 0.18 to 0.24 for social services, from 0.31 to 0.35 for price controls, and 0.33 to 0.36 for subsidies. Furthermore, the influence of egalitarian values on policy preferences measured by standardized coefficients remains large after controlling for SES and institutions; 0.26 for social services, 0.33 for price controls, and 0.40 for subsidies. The significant effects of institutions and SES on egalitarian values and the 3 dependent variables represents only a fraction of the modeled effects in Diagram 1 lending the most validity to Hypothesis 3.

(Tables $7 \& 8$ about here)

In order to test the overall goodness-of-fit (GOF) of the model I impute missing data instead of losing almost half of the cases to incomplete information. Therefore, I utilize multiple imputation of missing data with Stata SE 10.0 Statistical Software Package (Royston, 2004) prior to running the SEM 
that includes all variables (not the sheaf). In some cases there was not enough information to successfully impute missing values and preserve the integrity of the data leaving a total of $N=11,589$ (out of a possible $N=13,294$ ). The model achieves a RMSEA of 0.072 (for all other GOF measures see Technical Appendix). Note that the RMSEA (and all other not shown GOF measures) show that my model is an improvement from the independence model, and within generally accepted ranges in the literature as representing a decent fitting model (Byrne, 2001).

\section{COUNTRY LEVEL COMPARISONS}

In order to test for country level differences I run separate structural equation models for each country. This reveals a consistent influence of egalitarian values on support of social welfare policies across all five nations. The following tables show metric coefficients, significance tests, and slope tests for all independent variables on dependent variables government control of social services, price controls and subsidies (Table 9). Slope tests using Australia as the control confirm that for each dependent variable only one nation differs significantly in the relationship of egalitarian values to a given welfare policy. For government control of social services and subsidies, Finland has a significantly lower coefficient ( 0.13 and 0.13 respectively) albeit in the same direction as Australia and all other nations. For price controls, Poland differs from Australia and again it is in the same direction, this time representative of a slightly stronger relationship (0.31).

(Tables 9 about here)

In Australia, Bulgaria and Poland those who see government as more effective tend to support each of the 3 policies similarly, whereas in Finland and the Netherlands the relationship is different and small or insignificant in each case. As for the independent variables, socioeconomic status and demographics vary widely across all five nations and in most cases the relationships are not significant. The exception is education in Bulgaria and Poland. In support of price controls and subsidies those Bulgarians who are more educated are more likely to oppose the policies. For all three policies, the Poles who are more educated are more likely to oppose the given policy. These relationships vary markedly 
from the other three nations where education has no significant effect on policy preferences in any of the models.

The important fact remains that egalitarian values functions similarly in all five nations in its relationship to public preferences of welfare policy.

\section{DISCUSSION}

Those who favor reducing social inequality are most likely to support welfare-related policies of government control of social services, and price controls and subsidies for basic needs of electricity, food, housing, and health care. This relationship holds true in all five nations. It does not vary in magnitude in four out of five nations for all three policies. Finns who are more egalitarian are slightly less likely than the other nations to support government control of social services and subsidies, and Poles who are more egalitarian are slightly more likely to support price controls than the others but both show a large influence of egalitarian values on policy support like the others. These findings have relevance for those who seek to understand support or opposition to welfare and redistributive policies, such as governing officials or citizens seeking to harness collective action. For those who study attitude formation and social theory, these findings support instrumental rationality as a legitimate social force and a theory warranting further consideration today. Furthermore, these findings greatly expand on U.S. based research showing the ideology-policy link, making it generalizable to both disparate advanced and formerly Communist nations.

Citizens of formerly Communist countries are more likely to support price controls and subsidies than their traditionally capitalistic counterparts. The publics in Bulgaria and Poland are far more supportive of all three policies than those in Australia, The Netherlands, and Finland. This finding is consistent with the work of Sikora and Kelley (1999) who point out that the public still tended to favor centrally planned economies after the fall of Communism and into the mid 90s. One plausible explanation is that after the break-up of the U.S.S.R. most formerly Communist nations found their economies toppled 
and unstable. This painful transition suggests that the new national institutions had not yet realized their potential in terms of benefiting the public. Alternatively, this finding lends credence to the claims that institutions shape opinions at the national level and leave behind a policy regime legacy after dissolution. The salience of this finding rests in the fact that the instillation and disintegration of Communism in Poland and Bulgaria provides a natural experiment as both of these countries did not elect Communism; rather it arrived via Soviet tanks.

Socioeconomic-status (SES) and demographic characteristics including family income, education, occupational status, sex, age, and church attendance show little to no importance in explaining support for welfare policies. Put another way, what an individual stands to gain or lose from these policies matters only slightly, calling into question those who argue for material self-interest in explaining public opinion. What matters 2 to 3 times more than three SES factors combined, and exponentially more than each individually, is the presence of economic egalitarian values. Again this re-asserts that instrumental rationality is the vehicle for support of government control of social services, and price controls and subsidies over self-interest.

A side finding emerged in this analysis: that education in five out of six instances in Bulgaria and Poland proved extremely important in addition to egalitarian ideology in shaping welfare policy opinion unlike the other three countries where it mattered little to none. In these two nations the well educated tended to be more opposed to the three policies. I suggest that the well-educated in formerly Communist countries more easily adopted free-market ideology, and saw price controls and subsidies as simply reverting back to Communism. As others demonstrate, the educated citizens of formerly Communist nations were used to being in a position of material privilege before and after the transition, as well as having exposure to the benefits of the West (Arts \& Gijsberts, 1998; Firebaugh \& Sandu, 1998). This is useful for students of post-Communist studies, institutional arrangements, markets, and attitude formation; as a rift clearly exists between those with high educational attainments versus those without in formerly Communist countries, whereas amongst the traditionally democratic states there is not. 
While these findings are consistent with Andre $\beta$ and Heien (2001) concerning variation in overall levels of support for welfare policies across regime types, they are contentious compared to their claims that there is great variation in the role of ideology in shaping policy preferences across regimes. They show that egalitarian ideology has a strong role in influencing welfare preferences in Norway, a small role in formerly Communist East Germany and no role in the U.S. and West Germany. My findings show that in both free market and formerly Communist nations egalitarian ideology functions nearly identically in its level of influence on policy preferences. This discrepancy may be a result of their measurement of egalitarianism in negative terms; in other words pro-market attitudes. I propose that these may be two disparate ideological constructs instead of poles on the egalitarian spectrum. Further research is necessary as the ISEA does not yet cover the countries investigated by Andre $\beta$ and Heien via the ISSP.

Looking ahead, as the economies in Europe, North America, South America, Africa, and Asia move towards integration (through the bourgeoning common markets of the European Union, North American Free Trade Agreement, Southern Common Market (MERCOSUR), the African Union, and the rapid growth of trade and knocking down of trade-barriers bringing a common Asian market ever closer to reality) the ability of social scientists and policy makers to understand the strong allegiance of postCommunist and potentially post-socialist countries to welfare-like policies will be a key component of eventual social integration (i.e. socioeconomic policy formation) along with the resolution of disputes.

Overall, these findings have implications for public opinion researchers, especially those concerned with public policy preferences. It appears that support for welfare-like policies comes from ideological notions and somewhat from institutional policy regimes. They support the research of students of Weber's means-ends instrumental rationality. They call for further research in other nations from the periphery that are in the process of developing social welfare systems, and in general cross-national comparisons to see if this ideological influence on policy is true everywhere as it is in these five disparate countries. Additional analyses might further investigate the relatively low impact of self-interest on these policy preferences as all walks of the public might stand to benefit from them, especially with government provisions; thus looking at what parents of children who are day-care aged, the regularly 
infirm, or those in college and universities think specifically might show a stronger influence of self-

interest. Finally, further analysis would prove beneficial for welfare scholars in particular that

incorporates some of the other typologies of welfare states such as conservative and Mediterranean, not

just liberal, social democratic, and formerly Communist Eastern Europe (Arts \& Gelissen, 2002; Esping-

Andersen, 1990). Finally, academics, politicians and social organizers alike should understand that

support for various programs and policies are ideologically grounded and understand that garnering or

harnessing support requires demonstrating to masses that given policies will fulfill their ideological goals.

\section{REFRERENCES}

Alesina, A., \& Glaeser, E. L. (2004). Fighting Poverty in the US and Europe: A World of Difference. Oxford: Oxford University Press.

Alexeev, M., \& Leitzel, J. (2001). Income distribution and price controls: Targeting a social safety net during economic transition. European Economic Review, 45, 1647-1663.

Andre $\beta$, H., \& Heien, T. (2001). Four worlds of welfare state attitudes? A comparison of Germany, Norway, and the United States. European Sociological Review, 17(4), 337-356.

Arts, W., \& Gelissen, J. (2002). Three worlds of welfare capitalism or more? A state-of-the-art report. Journal of European Social Policy, 12(2), 137-158.

Arts, W., \& Gijsberts, M. (1998). After the velvet revolutions: Altered life-chances, fragile legitimacy, and split consciousness in post-Communist Eastern Europe. Social Justice Research, 11(2), 143-171.

Barnekov, T. K., \& Raffel, J. A. (1990). Public management of privatization. Public Productivity \& Management Review, 14(2), 135-152.

Barr, N. A. (2000). Economic theory and the welfare state: A survey and interpretation. Journal of Economic Literature, 30, 741-803.

Bean, C., \& Papadakis, E. (1998). A comparison of mass attitudes toward the welfare state in different institutional regimes. International Journal of Public Opinion Research, 10(3), 211-236.

Beers, C. V., \& Bergh, J. C. V. D. (2001). Perseverance of perverse subsidies and their impact on trade and environment. Ecological Economics, 36(3), 475-486.

Blanchard, O. (1997). The Economics of Post-Communist Transition. Oxford: Clarendon Press.

Blekesaune, M., \& Quadagno, J. (2003). Public attitudes toward welfare state policies: A comparative analysis of 24 nations. European Sociological Review, 19(5), 415-427.

Block, W. (1995). Professor Modigliani on price controls: The baleful influence of the perfectly competitive model. International Journal of Social Economics, 22(5), 27-30.

Bratman, M. E. (1999). Intention, Plans, and Practical Reason. Chicago: University of Chicago Press.

Brooks, C., \& Manza, J. (2007). Why Welfare States Persist: The Importance of Public Opinion in Democracies. Chicago: University of Chicago Press.

Brooks, C., \& Manza, J. (2006). Social policy responsiveness in developed democracies. American Sociological Review, 71(3), 474-494.

Burstein, P. (2003). The impact of public opinion on public policy: A review and an agenda. Political Research Quarterly, 56(1), 29-40. . (2006). Why estimates of the impact of public opinion on public policy are too high: Empirical and theoretical implications. Social Forces, 84(4), 2273-2289.

Burstein, P., \& Linton, A. (2002). The impact of political parties, interest groups, and social movement organizations on public policy: Some recent evidence and theoretical concerns. Social Forces, 81(2), 381408.

Byrne, B. M. (2001). Structural Equation Modeling with AMOS: Basic Concepts, Applications, and Programming. New Jersey: Lawerence Erlbaum. 
Campbell, J. L. (2002). Ideas, politics, and public policy. Annual Review of Sociology, 28, 21-38.

Cnaan, R. A., Hasenfeld, Y., Cnaan, A., \& Rafferty, J. (1993). Cross-cultural comparison of attitudes toward welfare state programs: Path analysis with log-linear models. Social Indicators Research, 28, 21-50.

Cramer, D., Howitt, D. L., and Howitt, D. ( 2004). The Sage Dictionary of Statistics. London: Sage.

DiMaggio, P. J., \& Powell, W. W. (1983). The iron cage revisited: Institutional isomorphism and collective rationality in organizational fields. American Sociological Review, 48(2), 147-160.

Eastwood, J. (2005). The role of ideas in Weber's theory of interests. Critical Review, 17(1), 89-100.

Esping-Andersen, G. (1990). The Three Worlds of Welfare Capitalism. Oxford: Oxford University Press.

Esping-Andersen, G., Gallie, D., \& Hemerijk, A. (2002). Why We Need a New Welfare State. New York: Oxford University Press.

Feldman, S., \& Steenbergen, M. R. (2001). The humanitarian foundation of public support for social welfare. American Journal of Political Science, 45(3), 658-677.

Firebaugh, G., \& Sandu, D. (1998). Who supports marketization and democratization in post-Communist Romania? Sociological Forum, 13(3), 521-541.

Friedman, M. (2002). Capitalism and Freedom: Fortieth Anniversary Edition. Chicago: University of Chicago Press.

Gelissen, J. (2000). Popular support for institutionalised solidarity: A comparison between European welfare states. International Journal of Social Welfare, 9, 285-300.

Gorter, H. D., Nielson, D. J., \& Rausser, G. C. (1992). Productive and predatory public policies: Research expenditures and producer subsidies in agriculture. America Journal of Agricultural Economics, 74(1), 27 37.

Hacker, J. (2004). Privatizing risk without privatizing the welfare state: The hidden politics of social policy retrenchment in the United States. American Political Science Review, 98(2), 243-260.

Hasenfeld, Y., \& Rafferty, J. A. (1989). The determinants of public attitudes toward the welfare state. Social Forces, 67(4), 1027-1048.

Hayek, F. A. (1996). Individualism and the Economic Order. Chicago: University of Chicago Press.

Henderson, T. L., Monroe, P. A., Garand, J. C., \& Burts, D. C. (1995). Explaining public opinion toward government spending on child care. Family Relations, 44(1), 37-45.

Hill, K. Q., \& Hinton-Andersson, A. (1995). Pathways of representation: A causal analysis of public opinion-policy linkages. American Journal of Political Science, 39(4), 924-935.

Hobbes, T. (1994). Leviathan. Indiana: Hackett Publishing.

Iversen, T., \& Soskice, D. (2001). An asset theory of social policy preferences. American Political Science Review, 95(4), 875-893.

Jacobs, L. R. (1992). Institutions and culture: Health policy and public opinion in the U.S. and Britain. World Politics, 44(2), 179-209.

Jæger, M. M. (2006). What makes people support public responsibility for welfare provision: Self-interest or political ideology? A longitudinal approach. Acta Sociologica, 49(3), 321-338.

Jepperson, R. (1991). Institutions, institutional effects, and institutionalism. In W. W. Powell \& P. J. DiMaggio (Eds.), The New Institutionalism in Organizational Analysis (pp. 143-163). Chicago: University of Chicago Press.

Jöreskog, K. G., \& Sörbom, D. (1982). Recent developments in structural equation modeling. Journal of Marketing Research, 19(4), 404-416.

Kalberg, S. (1980). Max Weber's types of rationality: Cornerstones for the analysis of rationalization processes in history. American Journal of Sociology, 85(5), 1145-1179.

Kelley, J. (1990). The failure of a paradigm: Log-linear models of social mobility. In J. Clark, C. Modgil, \& S. Modgil (Eds.), John H. Goldthorpe: Consensus and Controversy (pp. 319-346). London: Falmer.

Kelley, J., Evans, M., \& Zagorski, K. (2007). Codebook: International Survey of Economic Attitudes, fourth edition. International Survey. Retrieved June 18, 2009, from http://www.international-survey.org. . (2007). International Survey of Economic Attitudes: 1994-1999 Data Cleaned Version; Computer Readable Datafile. International Survey. Retrieved June 18, 2009, from http://www.internationalsurvey.org. (Original data published in 1999).

Larsen, C. A. (2008). The institutional logic of welfare attitudes: How welfare regimes influence public support. Comparative Political Studies, 41(2), 145-168.

Lipset, S. M. (1997). American Exceptionalism: A Double-Edged Sword. New York: W. W. Norton \& Company.

Lipsey, R. G. (1977). Wage-price controls: How to do a lot of harm by trying to do a little good. Canadian Public Policy, 3(1), 1-13. 
Lipsmeyer, C. S. (2003). Welfare and the discriminating public: Evaluating entitlement attitudes in post-Communist Europe. Policy Studies Journal, 31(4), 545-564.

Marx, K. (1927). Capital: A Critique of Political Economy. (F. Engels, Ed., S. Moore \& E. Aveling, Trans.) (3rd ed.). Chicago: Charles H. Kerr and Company.

Mehrtens III, F. J. (2004). Three worlds of public opinion? Values, variation, and the effect on social policy. International Journal of Public Opinion Research, 16(2), 115-143.

Meltzer, A. H., \& Richard, S. F. (1981). A rational theory of the size of government. The Journal of Political Economy, 89(5), 914-927.

Miller, D. T. (1999). The norm of self-interest. American Psychologist, 54(12), 1053-1060.

Mills, D. Q. (1975). Some lessons of price controls in 1971-1973. Bell Journal of Economics, 6(1), 3-49.

Myers, N., \& Kent, J. (2001). Perverse Subsidies: How Tax Dollars Can Undercut the Environment and the Economy. Washington D.C.: Island Press.

Papadakis, E. (1993). Class interests, class politics and welfare state regime. The British Journal of Sociology, 44(2), 249-270.

Papadakis, E., \& Bean, C. (1993). Popular support for the welfare state: A comparison between institutional regimes. Journal of Public Policy, 13(3), 227-254.

Parry, T. R. (1997). Decentralization and privatization: Education policy in Chile. Journal of Public Policy, 17(1), 107-133.

Ricardo, D. (2006). Principles of Political Economy and Taxation. New York: Cosimo Classics.

Rockoff, H. (2004). Drastic Measures: A History of Wage and Price Controls in the United States (2nd ed.). Cambridge: Cambridge University Press.

Rockoff, H. (1981). Price and wage controls in four wartime periods. Journal of Economic History, 41(2), 381-401.

Roller, E. (1994). Ideological basis of the market economy: Attitudes toward distribution principles and the role of government in Western and Eastern Germany. European Sociological Review, 10(2), 105-117.

Rothstein, B. (1998). Just Institutions Matter: The Moral and Political Logic of the Universal Welfare State. Cambridge: Cambridge University Press.

Royston, P. (2004). Multiple imputation of missing values. Stata Journal, 4(3), 227-241.

Scott, W. R. (2001). Institutions and Organizations: Ideas and Interests. Thousand Oaks, CA: Sage. . (1987). The adolescence of institutional theory. Administrative Science Quarterly, 32(4), 493-511. . (2008). Approaching adulthood: The maturing of institutional theory. Theory and Society, 37(5), 427-442.

Sikora, J. (1997). A comparison of 1994/1995 International Survey of Economic Attitudes data with censuses. Worldwide Attitudes, 97, 1-15.

. (2005). Public attitudes to economic policy in East and West: Efficiency, subsidies and public ownership. Research in Social Stratification and Mobility, 23, 229-274.

Sikora, Joanna, and Jonathan Kelley. 1999. Attitudes to private and public ownership in East and West: Bulgaria, Poland, Finland and Australia 1994/97. Soviet and Post-Soviet Review, 26 (1), 13-42.

Smith, A. (2003). The Wealth of Nations. Toronto: Bantam Classics.

Smith, T. W. (1987). A report: The welfare state in cross-national perspective. The Public Opinion Quarterly, 51(3), 404-421.

Svallfors, S. (1997). Worlds of welfare and attitudes to redistribution: A comparison of eight Western nations. European Sociological Review, 13(3), 283-304.

Taylor-Gooby, P. (2001). Sustaining state welfare in hard times: Who will foot the bill? Journal of European Social Policy, 11, 133-147.

Thompson, L., \& Elling, R. C. (2000). Mapping patterns of support for privatization in the mass public: The case of Michigan. Public Administration Review, 60(4), 338-348.

Walker, M. (2009) World news: Europe's social benefits are at risk. Wall Street Journal, Eastern Edition, New York, NY. May, 15, 2009, A.6.

Weber, M. (1947). The Theory of Economic and Social Organization. (A. Henderson \& T. Parson, Trans.). New York: Oxford University Press. . (1968). Economy and Society. (G. Roth \& C. Wittich, Trans.). New York: Bedminister.

Wolfle, L. M. (2003). The Introduction of path analysis to the social sciences, and some emergent themes: An annotated bibliography. Structural Equation Modeling, 10(1), 1-34. 


\section{TABLES AND FIGURES}

TABLE 1 Measurement and descriptives for all variables

\begin{tabular}{|c|c|c|c|c|c|}
\hline Variable & Measurement & $N$ & Mean $^{a}$ & s.d. & Reliability \\
\hline Education & Years of school completed & 13,182 & 11.2 & 3.3 & 0.87 \\
\hline Occupational status & Scored from 0 (farm laborer) to 100 (higher professional) & 12,272 & 46.1 & 28.0 & 0.88 \\
\hline Family income & $\begin{array}{l}\text { Ratio to average wages of semi-skilled, full-time male } \\
\text { workers in respondent's country }\end{array}$ & 11,727 & 1.6 & 1.5 & 0.71 \\
\hline Male & Male $=1 ;$ Female $=0$ & 13,152 & 0.5 & 0.5 & 0.99 \\
\hline Age & In years & 13,294 & 46.7 & 16.1 & 1.00 \\
\hline Church attendance & Natural log of days per year; "never" scored at .5 days & 13,050 & 1.5 & 1.8 & 0.84 \\
\hline Former Communist & Bulgaria and Poland $=1$; Other $=0$ & 13,294 & 0.4 & 0.5 & 1.00 \\
\hline Economic egalitarianism & Multi-item, see Table 2 & $\mathrm{n} / \mathrm{a}$ & $57.3(29)$ & 28.6 & 0.90 \\
\hline Government effectiveness & Multi-item, see Table 3 & $\mathrm{n} / \mathrm{a}$ & $30.3(50)$ & 22.9 & 0.80 \\
\hline $\begin{array}{l}\text { Government control of social } \\
\text { services }\end{array}$ & Multi-item, see Table 4 & $\mathrm{n} / \mathrm{a}$ & $57.6(10)$ & 29.6 & 0.89 \\
\hline Price controls for basic needs & Multi-item, see Table 5 & $\mathrm{n} / \mathrm{a}$ & $49.8(39)$ & 24.8 & 0.82 \\
\hline Subsidies for basic needs & Multi-item, see Table 6 & $\mathrm{n} / \mathrm{a}$ & $54.1(30)$ & 25.7 & 0.79 \\
\hline
\end{tabular}

${ }^{\mathrm{a}}$ Means for multi-item scales calculated from unequal interval scoring, see Technical Appendix (http://www.international-survey.org) and numbers in parentheses represent unequal interval midpoint for all scale variables except government control of social services where 10 equals some government control and 100 equals total control.

Note: Test retest reliability for single-item variables calculated from the Australian survey; alpha reliabilities calculated for multi-item variables. 
TABLE 2 Measurement of economic egalitarian values

Do you agree or disagree...

Differences in income in \{country\} are too large

It is the responsibility of the government to reduce the differences in There is too much of a difference between rich and poor in this country Income and wealth should be redistributed toward ordinary people One of the most important aims in this country over the next ten years should be to reduce differences between rich and poor income between people with high incomes and those with low incomes

Answer choices, interval coding, and

\begin{tabular}{ccccccc}
\multicolumn{7}{c}{ frequencies(\%) } \\
\hline No!! & No & $? ?$ & Yes & Yes!! & Total \\
$(0)$ & $(7)$ & $(29)$ & $(53)$ & $(100)$ & $\%$ & Mean \\
\hline 1 & 10 & 13 & 37 & 39 & 100 & 63 \\
5 & 17 & 17 & 34 & 28 & 100 & 51 \\
2 & 9 & 12 & 36 & 41 & 100 & 65 \\
4 & 15 & 22 & 33 & 26 & 100 & 52 \\
4 & 11 & 17 & 37 & 31 & 100 & 56 \\
\end{tabular}

Note: $\mathrm{N}=13,294$ with minor variation in response rates. Mean non-response 5\%. Table presented verbatim in English, translated for nonEnglish speaking countries. Interval coding derived from ordinal probit regression (details in Technical Appendix) 
TABLE 3 Measurement of government effectiveness

Government and private enterprises both have their good points and bad ones. Which do you think is...

\begin{tabular}{rcccccccc} 
& \multicolumn{8}{c}{ Answer choices, coding, and frequencies(\%) } \\
\cline { 2 - 9 } & Priv!! & Priv & $=$ & Govt & Govt!! & Total & \\
& $(0)$ & $(24)$ & $(50)$ & $(85)$ & $(100)$ & $\%$ & Mean \\
\cline { 2 - 9 } Most efficient, most productive? & 23 & 49 & 15 & 10 & 4 & 100 & 31 \\
Most flexible, responds quickly to & 27 & 53 & 11 & 7 & 3 & 100 & 26 \\
Most profitable? & 23 & 47 & 15 & 11 & 4 & 100 & 32 \\
\hline
\end{tabular}

Note: $\mathrm{N}=13,294$ with minor variation in response rates. Mean non-response 4\%. Table presented verbatim in English, translated for non-English speaking countries. Interval coding derived from ordinal probit regression (details in Technical Appendix) 
TABLE 4 Measurement of government control of social services

What part should the government play in running companies in these industries...

\begin{tabular}{rcccccc} 
& \multicolumn{6}{c}{ Answer choices, coding, and frequencies(\%) } \\
\cline { 2 - 8 } & None & Some & Imp. & All & Total & \\
& $(0)$ & $(10)$ & $(12)$ & $(100)$ & $\%$ & Mean \\
\cline { 2 - 8 } Hospitals & 2 & 21 & 39 & 39 & 100 & 67 \\
Schools & 2 & 24 & 40 & 34 & 100 & 63 \\
Universities & 5 & 29 & 35 & 31 & 100 & 57 \\
Old age homes & 4 & 32 & 33 & 32 & 100 & 57 \\
\hline Dav-care centers for children & 8 & 37 & 30 & 26 & 100 & 50 \\
Ond dentists & 7 & 34 & 32 & 27 & 100 & 52 \\
\end{tabular}

Note: $\mathrm{N}=13,294$ with minor variation in response rates. Mean non-response $5 \%$. Table presented verbatim in English, translated for non-English speaking countries. Interval coding derived from ordinal probit regression (details in Technical Appendix) 
TABLE 5 Measurement of price controls for basic needs

Should the government regulate prices or should they be set by the free market...

\begin{tabular}{rccccccc} 
& \multicolumn{7}{c}{ Answer choices, coding, and frequencies(\%) } \\
\cline { 2 - 8 } & Free!! & Free & $=$ & Govt & Govt!! & Total \\
Electricity & 5 & 16 & 19 & 35 & 26 & 100 & 54 \\
Basic foods & 9 & 28 & 21 & 25 & 17 & 100 & 43 \\
Rents for houses and flats & 8 & 27 & 23 & 27 & 16 & 100 & 43 \\
s fee and hospital charges & 3 & 9 & 17 & 42 & 30 & 100 & 59 \\
\hline
\end{tabular}

$\begin{array}{ccccccc}\text { Doctor's fee and hospital charges } & 3 & 9 & 17 & 42 & 30 & 100\end{array}$ verbatim in English, translated for non-English speaking countries. Interval coding derived from ordinal probit regression (details in Technical Appendix) 
TABLE 6 Measurement of subsidies for basic needs

To keep prices low, should the government subsidize the production of...

\begin{tabular}{rccccccc} 
& \multicolumn{7}{c}{ Answer choices, coding, and frequencies(\%) } \\
\cline { 2 - 8 } & No!! & No & $? ?$ & Yes & Yes!! & Total & \\
& $(0)$ & $(11)$ & $(30)$ & $(57)$ & $(100)$ & $\%$ & Mean \\
\cline { 2 - 8 } Electricity & 6 & 17 & 16 & 37 & 23 & 100 & 51 \\
Basic foods & 8 & 23 & 17 & 33 & 20 & 100 & 46 \\
Construction of houses and flats & 6 & 20 & 19 & 34 & 21 & 100 & 48 \\
Doctors and hospitals & 2 & 6 & 8 & 39 & 45 & 100 & 70 \\
\hline
\end{tabular}

Note: $\mathrm{N}=13,294$ with minor variation in response rates. Mean non-response $4 \%$. Table presented verbatim in English, translated for non-English speaking countries. Interval coding derived from ordinal probit regression (details in Technical Appendix) 


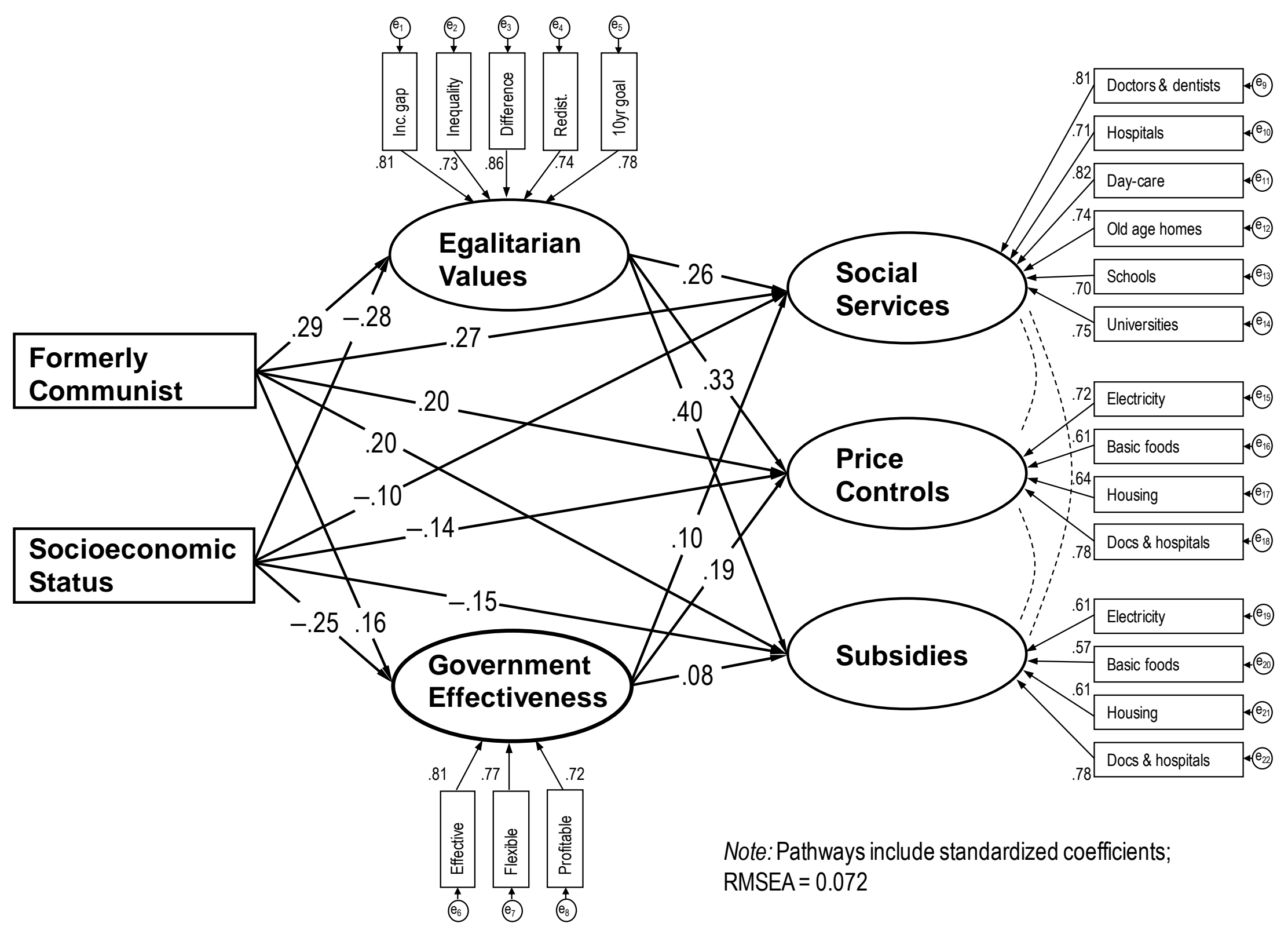


TABLE 7 Stage One: Strucutral equation estimates correcting for measurement error for dependent variables without SES and institutional variables

\begin{tabular}{lccccccccc}
\hline & \multicolumn{3}{c}{\begin{tabular}{c} 
Government control of \\
\cline { 2 - 11 }
\end{tabular}} & \multicolumn{3}{c}{ social services } & \multicolumn{2}{c}{ Price controls for basic needs } & \multicolumn{3}{c}{ Subsidies for basic needs } \\
\cline { 2 - 12 } & Metric & s.e. & Std. & Metric & s.e. & Std. & Metric & s.e. & Std. \\
\hline Egalitarian values & 0.31 & 0.01 & $0.36 * * *$ & 0.34 & 0.01 & $0.43 * * *$ & 0.36 & 0.01 & $0.52^{* * * *}$ \\
Government effective & 0.15 & 0.01 & $0.13 * * *$ & 0.24 & 0.01 & $0.23 * * *$ & 0.10 & 0.01 & $0.11^{* * *}$ \\
Age & -0.01 & 0.02 & ns & 0.07 & 0.01 & $0.05 * * *$ & -0.06 & 0.01 & $-0.04 * * *$ \\
Male & 2.74 & 0.36 & $0.06 * * *$ & -0.90 & 0.43 & $-0.02 *$ & -2.38 & 0.38 & $-0.06 * * *$ \\
Church attendance & 0.14 & 0.16 & ns & 0.48 & 0.15 & $0.03 * *$ & 0.69 & 0.13 & $0.05 * * *$ \\
Squared multiple correlation & & 0.18 & & & 0.31 & & & 0.33 & \\
\hline
\end{tabular}

${ }^{3}$ Standardized regression estimates taken from seprate SEM where income, occupational status and education are combined into a sheaf variable.

Note: $\mathrm{N}=13,294$. "Std." refers to standardized coefficients. 
TABLE 8 Stage Two: Strucutral equation estimates correcting for measurement error for dependent variables with SES and institutional variables

Government control of

social services

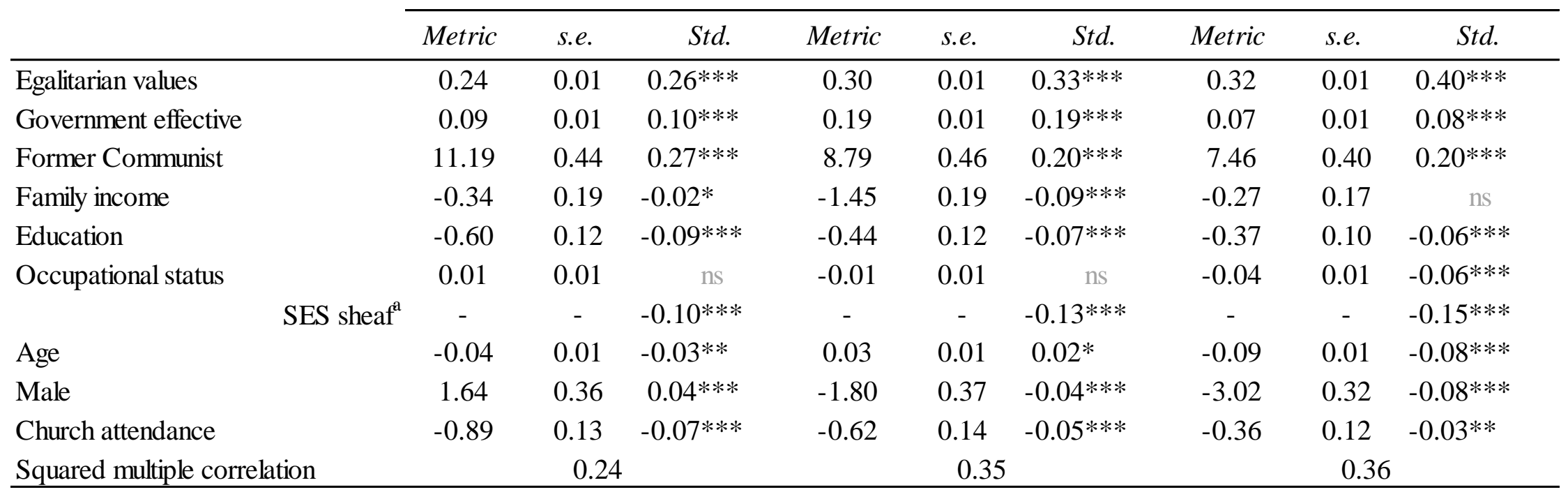

${ }^{\text {a }}$ Standardized regression estimates from seprate SEM where income, occupational status and education are combined into a sheaf variable.

Note: $\mathrm{N}=13,294$. "Std." refers to standardized coefficients. 
TABLE 9 Metric coefficients from structural modeling by country

Government control of social services

\begin{tabular}{lccccc}
\hline & Australia & Bulgaria & Finland & Netherlands & Poland \\
\cline { 2 - 6 } Egalitarian values & 0.17 & 0.23 & 0.13 & 0.18 & 0.22 \\
Government effective & 0.16 & 0.14 & $\mathrm{~ns}$ & $\mathrm{~ns}$ & 0.14 \\
Family income & $\mathrm{ns}$ & -2.55 & $\mathrm{~ns}$ & $\mathrm{~ns}$ & -1.32 \\
Education & $\mathrm{ns}$ & $\mathrm{ns}$ & $\mathrm{ns}$ & $\mathrm{ns}$ & -1.70 \\
Occupational status & $\mathrm{ns}$ & $\mathrm{ns}$ & $\mathrm{ns}$ & $\mathrm{ns}$ & $\mathrm{ns}$ \\
Age & -0.07 & $\mathrm{~ns}$ & $\mathrm{~ns}$ & $\mathrm{~ns}$ & $\mathrm{~ns}$ \\
Male & 3.93 & $\mathrm{~ns}$ & 3.12 & 4.27 & $\mathrm{~ns}$ \\
Church attendance & -0.80 & $\mathrm{~ns}$ & $\mathrm{n} / \mathrm{a}$ & $\mathrm{ns}$ & $\mathrm{ns}$ \\
\hline
\end{tabular}

Price controls for basic needs

\begin{tabular}{lccccc}
\hline & Australia & Bulgaria & Finland & Netherlands & Poland \\
\cline { 2 - 6 } Egalitarian values & 0.24 & 0.28 & 0.23 & 0.27 & 0.31 \\
Government effective & 0.21 & 0.15 & 0.16 & $\mathrm{~ns}$ & 0.19 \\
Family income & -1.68 & $\mathrm{~ns}$ & $\mathrm{~ns}$ & -2.38 & -1.14 \\
Education & $\mathrm{ns}$ & -1.71 & $\mathrm{~ns}$ & $\mathrm{~ns}$ & -1.26 \\
Occupational status & $\mathrm{ns}$ & $\mathrm{ns}$ & $\mathrm{ns}$ & $\mathrm{ns}$ & $\mathrm{ns}$ \\
Age & $\mathrm{ns}$ & $\mathrm{ns}$ & $\mathrm{ns}$ & $\mathrm{ns}$ & $\mathrm{ns}$ \\
Male & -1.81 & 1.53 & -2.80 & $\mathrm{~ns}$ & $\mathrm{~ns}$ \\
Church attendance & $\mathrm{ns}$ & $\mathrm{ns}$ & $\mathrm{ns} / \mathrm{a}$ & $\mathrm{ns}$ & $\mathrm{ns}$ \\
\hline
\end{tabular}

Subsidies for basic needs

\begin{tabular}{lccccc}
\hline & Australia & Bulgaria & Finland & Netherlands & Poland \\
\cline { 2 - 6 } Egalitarian values & 0.28 & 0.29 & 0.13 & 0.23 & 0.29 \\
Government effective & 0.10 & 0.12 & 0.07 & ns & 0.05 \\
Family income & -1.77 & 2.41 & -0.90 & -2.06 & $\mathrm{~ns}$ \\
Education & $\mathrm{ns}$ & -1.62 & $\mathrm{~ns}$ & $\mathrm{~ns}$ & -0.80 \\
Occupational status & $\mathrm{ns}$ & $\mathrm{ns}$ & $\mathrm{ns}$ & $\mathrm{ns}$ & $\mathrm{ns}$ \\
Age & -0.12 & $\mathrm{~ns}$ & $\mathrm{~ns}$ & $\mathrm{~ns}$ & $\mathrm{~ns}$ \\
Male & -3.78 & $\mathrm{~ns}$ & -2.78 & -3.49 & -1.86 \\
Church attendance & $\mathrm{ns}$ & $\mathrm{ns}$ & $\mathrm{n} / \mathrm{a}$ & -1.03 & $\mathrm{~ns}$ \\
\hline
\end{tabular}

Note: Coefficients in italics significantly different from Australia in slope test; $\mathrm{p}<.01$. Coefficients listed in table are significant in structural model; $\mathrm{p}>.01$. Church attendance not measured in Finland. 